\title{
音響による高炉冷却函の破損検知法*
}

\author{
曽我 弘 ${ }^{* *} \cdot$ 南田勝宏 ${ }^{* *} \cdot$ 沢田保弘 ${ }^{* * *}$ \\ 楯岡正毅 $* * * *$. 合田純一 $* * * * *$
}

\section{A New Acoustic Method for Water Leak Detection of \\ Blast Furnace Cooling Boxes}

\author{
Hiromu Soga, Katuhiro Minamida, Yasuhiro SAwada \\ Masatake TATEOKA and Junichi GODA
}

\begin{abstract}
Synopsis:
A new method by which the detection of the damages of blast furnace cooling system is easily made was developed.

This is an acoustical method which detects the abnormal sounds caused by the entry of gas bubbles into cooling box or tuyere from the blast furnace through the small damaged part.

The result of the application of this method to the actual blast furnace was found to be quite satisfactory.
\end{abstract}

(Received 15 Dec. 1967)

\section{1. 緒}

高炉羽口や炉体の泠却の問題は炉体保護, 寿命の延長, 操業の安定性確保などの面からきわめて重要である. 一 方近年高炉の大型化に伴い羽口数も30 本におよぶもの もあり，膨大な数の泠却函の管理が必要となつてきた. 従来これらの管理は周囲条件が悪い場合が多くきわめて 困難な作業の1つとされていた.

一方冷却板や羽口からの炉内漏水は操業面からは最も 警戒すべき事故の1つであり，場合によつては大きな事 故と結びつくことも考えられる.

これら漏水管理に対して従来迅速，確実な方法がなく 現場担当者より強く改善が望まれていた．これに対し筆 者らは炉内から逆に冷却板内に混入するバブル音を検知 する方法を開発し，また音の発生過程，特徵を解析し実 用化した．本方法も完全とはいえないが，征来法にない すぐれた特長を持つており，今後広く利用されることを 期待したい.

\section{2. 実験結果概要}

\section{$2 \cdot 1$ 測定器}

本実験に.使用した基本装置は振動検出器, 低雑音増幅 器およびレシーバーから成る. 振動検出素子は加速度に 比例した出力を得る機械一電気变換素子で，その周波数 対感度の特性を Fig. 1 に示す. また低雑音増幅器は入
力換算雑音 $1 \mu \mathrm{V}$ (r.m.s) 程度のもので带域幅 $200 \mathrm{c} / \mathrm{s} \sim$ $10 \mathrm{kc} / \mathrm{s}$ ，増幅度は $30,40,55 \mathrm{db}$ の 3 段切換になつてい る.この出力は直接レシーバーに接続され耳で検知音を 聞くことができ，またコンパクトで携带に便利になつて いる. 全体の様子を Photo. 1 に示す.

\section{$2 \cdot 2$ モデル実験}

漏水検知に必要な基本的性質を知るため Fig. 2 に示 すモデルを作成した，これは冷却板を 2 段に連結し，一 方の先端に数種の小孔をあけ，漏水に伴う音の性質や逆 に冷却板に混入してくるバブル音の性質などの解析に利 用した。

一般的にいえ壮，炉内圧力と泠却水の水圧との大小関 係によつて冷却函に小孔または小さな破損が生じた場合 には, 炉内への漏水が生ずる場合と逆に炉内ガスが冷却 水中に混入する場合があるが，実際の高炉羽口や泠却板 などの破損発生の場合は大破は别として，この2つの状 態が高炉内での激しい動圧变化によつて交互にくり返さ れながら漏水が進行してゆくと考えられる．ここでは漏 水にともなつて発生する音の特徵とバブルの発生による

* 昭和 42 年 10 月本会講演大会にて発表 昭和 42 年 12 月 15 日受付

** 八幡製鉄 (株) 東京研究所

*** 八幡製鉄 (株) 本社

**** 八幡製鉄 (株) 戸畑製造所

$* * * * *$ 八幡製鉄 (怢) 技術研究所 


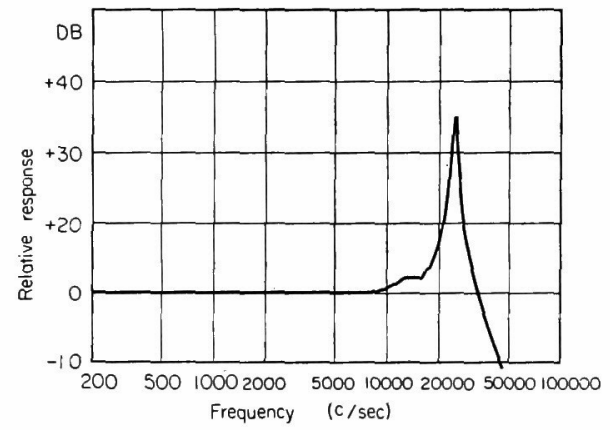

Fig. 1. Frequency response curve of the accelerometer.

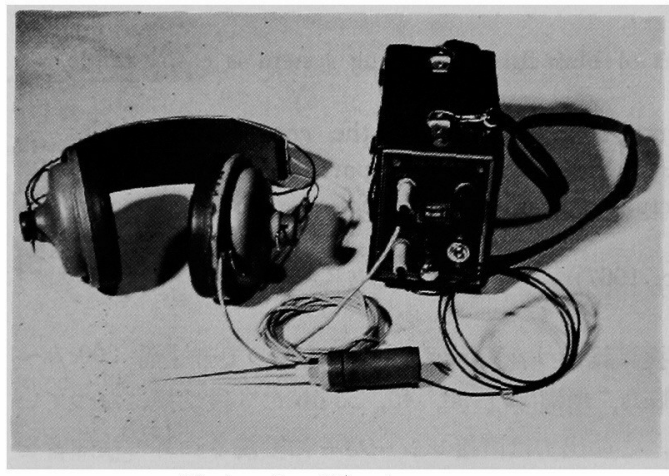

Photo. 1. The instrument.

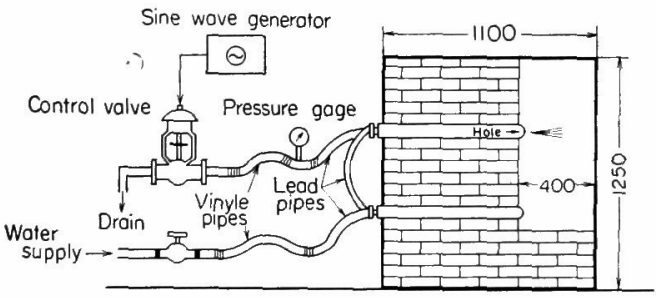

Fig. 2. The simulated model of the blast furnace wall.

音の両者について検知可能性宕怡討した，その結果以下 述べるようにバブル音が検知可能なことぶ明らかになつ t:

\section{$2 \cdot 2 \cdot 1$ 漏水音の検知}

一般に漏水がある場合それに伴つて漏水至が発生する ことは知られているが，この漏水振動音は漏水圧，破損 部形状，支持方法その他多くの要因によつて異なること が報告さ秃ている1。ここでは実物冷却板を用いて行な つた実験結果志要約する.

(i ) 漏水压が $1.5 \mathrm{~kg} / \mathrm{cm}^{2}$ 以下では漏水雑音はおお むね破損孔の面積に比例して大きくなる. (5 mm $\phi$ 以下 の面積)

（ii）水压が大きくなるにつれて，この傾向はかわり
低周波部分は面樍に比例して大きくなるが，高周波部は 逆に破損孔面積が大きくなると音の大きさは減少してゆ く. (4 kg $/ \mathrm{cm}^{2}$ 以下の圧力)

(iii) 漏水のない場合でも流量とともに増大寸る流量 雑音がある、これは升や流路の急激に変化する部分から 発生してパイプを伝播してくるものと考えられる.

(iv) 水压を周期的に変化させると, それに伴つて漏 水音の音色も周期的に変化し, 破損孔が小さいほどこの 変化は顕著である. したがつてこの性質を利用して漏水 検知を行ならことは原理的には可能である.

（v） 漏水に伴つて発生する漏水雑音の大きさは，後 述する高炉周辺の雑音と比較するとほぼ 1 桁小さく, 周 波数スペクトルの分布も特徵的な差はなく現場実用化と いう観点からはかなり困難と思われる.

\section{$2 \cdot 2 \cdot 2$ バブル音の検知}

瞬時的にせよ炉内圧が冷却水水压より大きくなれば破 損部からガスが混入しバブルとなつて外部に排出され る.ここでは前記モデルと平行してプラスチックの実物 大モデルでこのバルブの生成過程を観察した．この生成 過程は羽口，泠却板ともほぼ共通しておりバブル音によ つて破損を検知する場合の基礎になる，要約すると次の ようになる。

（i）破損部から泠却板内に入つたガスはバブルとな つて流されてゆくが，このパブル生成のとき音を発生す る.しかしこの音は泠却板が強く固定されているときに は外部に到達するまでにかなり減衰する.

（ii）冷却板破損部で生成したバブルは泠却水ととも に出口側に流れてゆき, 泠却板の傾斜や排水パイプ取付 部の構造によつて決まる流速の遅い部分に合体して一時 たをる。

(iii）合体して集まつたバブルはある程度以上の大き さになると一気に排出され，このとき小さなバブルに分 裂して音を発生する．このバブルの大きさは流速や排水 パイプの径で決まる大きさになる.もちろん平均とした であり，個々にはかなり大小の差がある.

(iv) バブルには固有振動数があり，かなり一定して いてほかの雑音と分離しやすい。（詳細は 3.1 参照)

（v）一般にバブルが連続的に冷却板破損部から混入 しても上記の過程により，排出されるのは間歇的となり したがつて外部で検知されるバブル音も間歇的となる. この頻度はガス压力, 泠却水の流速, 破損の程度によつ て異なるが，バブル音の大きさは (iii)からわかるごとく ほぼ同一である。

（vi）破損部で発生するバブルの大きさは，破損の程 度, 形状, 水の表面張力などの条件によつて変化し, ほ 
かの条件が同一なら破損個所が大きいほどバブルは大き い.また同一条件下なら破損個所が大きいほど聞こえる バブル音の頻度が多くなることがわかる。

\section{3 現場実験}

\subsection{1 高炉周辺の雑音}

音響的手段を高炉羽口などの漏水検知に利用する際， まず問題になるのは，大きな騒音源である羽口送風音， 周辺機械の音，および炉体自身の音がどの程度のものか およびその周波数スペクトルはどんなものかを知ること である.従来この種のデータはほとんど測定された例が ないので，数回の現場実験を行ない各種の条件下でのデ 一タを得ることができた。これらを整理要約すると次の ようになる。

（i）羽口で測定される音は送風により発生する音と 冷却水の排水音が主たる音源である。送風によつて発生 寸る音のスペクトルはかなり広い分布をもつているが羽 口の機械的固有振動数が $1 \cdot 6 \mathrm{kcsec} \sim 1 \cdot 8 \mathrm{kc} / \mathrm{sec}$ であるた め，この付近の成分が一段と強くあらわれる.

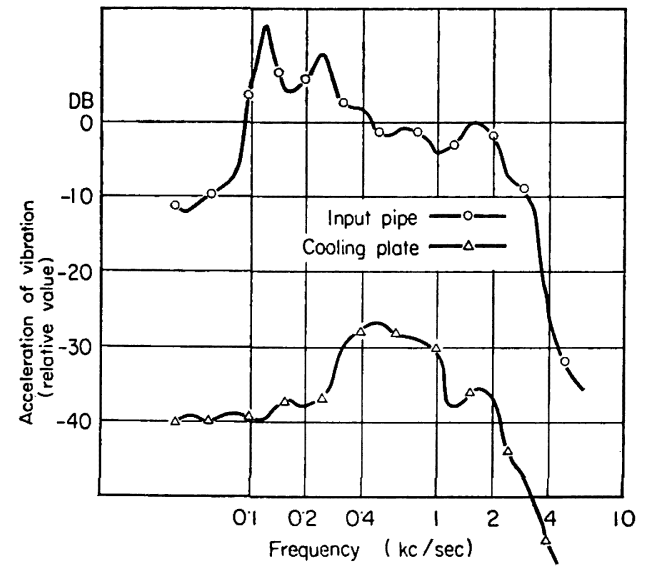

Fig. 3. Flow noise of the mantle cooling plate.

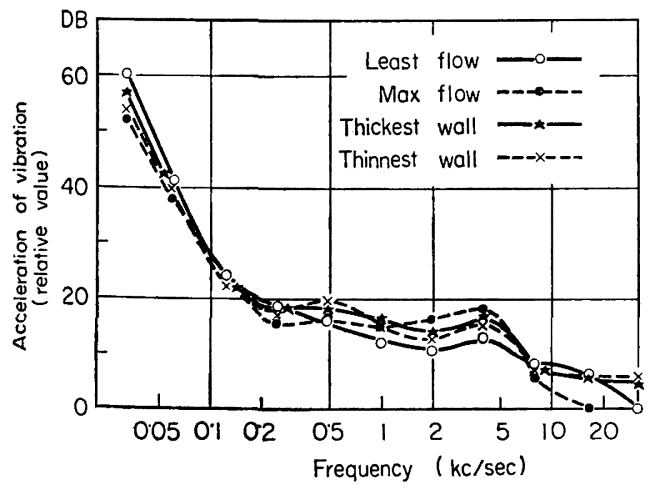

Fig. 4. Flow noise of the cooling plate. （ii）羽口でも泠却板でも炉体に埋込まれている部分 と給排水パイプとではかなり大きな差がある。これは支 持方法の違いによるものである. 一例をFig. 3 に示す.

(iii) 炉内の壁の厚み, 泠却水量の多少による相違を みるため，シャフト部（4 床）で測定した結果，これら による差異はほとえどなく，雑音の主たるものは炉内か らの振動之外部の風の音が鉄皮で集音されて伝達されて きたものと考えられる。

また羽口の雑音に比較して冷却板のそれは約 $1 / 10$ 程 度である。

(iv) 各高炉によつてスペクトルの形が変わつている が，これは被測定部の機械的特性が異なるためであろ 亏.

\section{$2 \cdot 3 \cdot 2$ 破損羽口の音}

高压水による泠却を行なつていない場合には，ほとん どの場合羽口泠却水圧より炉内压のほうが高くなりうる ので漏水と交互にバブル音を聞くことができる.

羽口破損の場合を要約すると次のごとくである。

（i）羽口付近では炉内静圧もかなり高いため，かな り微少なピンホールも検知可能である。

(ii)この傾向は測定時に泠却水の水生を下げるとさ らに顕著になる。

(iii) 各羽ロでの雑音は時間的にはあまり変動しな い.

(iv) 羽口，小丸，大丸とある場合にはこの順序で雑 音は小さくなつてゆく

（v）正常なものでも各羽ロごとの雑音レベルにはか なりの相異がある。

（vi）破損した羽口と正常なものとの音の波形を Photo. 2 に示す. 両者間に注この例のごとく明らかな変 化のあるものもあるが，これで判断できない例も相当多 い.したがつてこの中からバブル音を抽出する方法を考 える必要がある。

\section{3. バブル音の解析}

\section{$3 \cdot 1$ バブルの固有振動音}

バブルが生成された時に音が出ることは $2 \cdot 2 \cdot 2 て ゙$ 述べ たが，これはバブルが生成するとき表面張力の形で持つ ていたエネルギーが，バブル体積の変化となつて振動し ながら失われるため発生すると考光られる。この固有振 動数 $f_{0}$ は $(3 \cdot 1)$ 式によつて与えられる.

$$
f_{0}=(1 / 2 \pi) \cdot\left(3 \gamma \mathrm{P}_{0} / \rho \mathrm{R}_{0}^{2}\right)^{1 / 2}
$$

ただし $\gamma$ は定積比熱と定压比熱の比， $\mathrm{P}_{0}$ はガスの圧 力, $\rho$ は液体の密度, $\mathrm{R}_{0}$ は生成したバブルの半径であ る、またこの式は生成されたバブルが完全な球形をして 


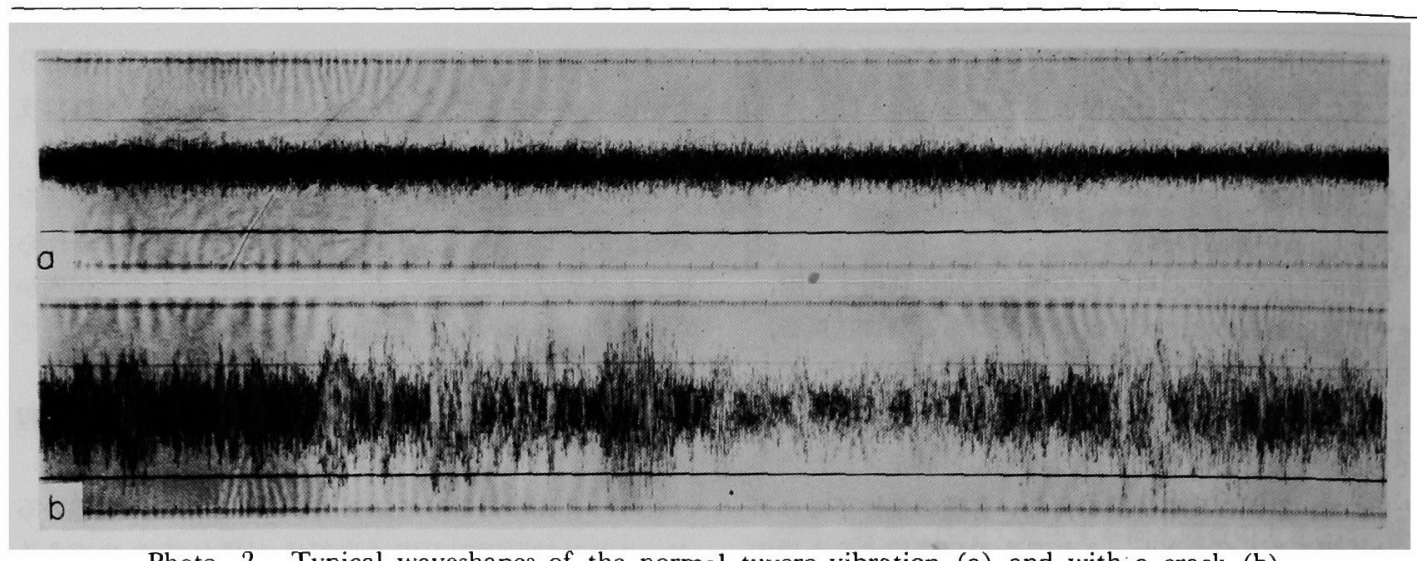

Photo. 2. Typical waveshapes of the normal tuyere vibration (a) and with a crack (b).

いる上仮定して導びかれるが，実際に球形から変形した 場合にも(3.1) 式がほとえどそのままの形で適用できる

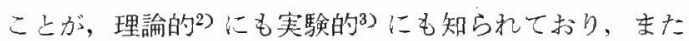
以下の解析例汃らも气の妥当性が示された。

いま高炉羽口付近で $\gamma=1 \cdot 35\left(\mathrm{CO}\right.$ と $\mathrm{CO}_{2}$ ガスの平 均), $P_{0}=2 \mathrm{~kg} / \mathrm{cm}^{2}, \quad \rho=1 \mathrm{~g} / \mathrm{cm}^{3}, \mathrm{R}_{0}$ を $[\mathrm{cm}]$ で表 わせは（3.1) 式は (3.2) 式となる.

$$
f_{0}=0 \cdot 45 / \mathrm{R}_{0} \quad[\mathrm{kc} / \mathrm{sec}]
$$

羽口や泠却板からのバブルが排出される上き生成する バブル半湰 $\mathrm{R}_{0}$ 注主上して排水パイプの径上流涑汇よつ て決まり，平均して $\mathbf{R}_{0}$ は 4 6[ $\left.\mathrm{mm}\right]$ 位であり (3.2) 式から $f_{0}$ の値は 750c/sec〜1120c/sec となる。実際に は音は相当歪えで㧍り高調波成分を多く含屯が，実測デ 一タからこのバブル音を検知解析することがー゙る。

\subsection{Sonagram ¿ Correlategraph}

上述のバブル音を解析するため汇は，バブル発生時の 音を長い時間の平均として解析したのて洨出できな い. そのため sonagram (一名声絞ともいう.) と correlategraph で解析した.

somagram 林横軸に時間をとり, 縦軸に周波数の直線 目盛をとつて，振幅の大小を漄淡で表示したものであ る。この装置は信号を一たん磁父ドラムに録音して，高 速で再生しながら 300c/sec の带域幅のフィルターを徐 々汇移動己せて作図するもので全体として $2.4 \mathrm{sec}$ の間 の記録が得られる。これ注音声解析の技術として広く利 用されている.

correlategraph は最初機械的方法を BENNETT が考穼 したガ゙，筆者らは实時間相関器らで実時問 correlategraph が得られるよう装置の一部改造它東大不井泰助教 授に依頼し，バブル音の解析心利用させてもらつた。こ

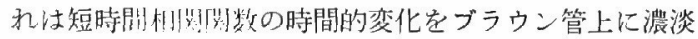
で表示できるょうにしたものである。すなわち (3.3) 式
で定義される自己相関関数を(3.4) 式で近似する.

$$
\begin{aligned}
& \varphi(\tau)=\lim _{i \rightarrow \infty} \frac{1}{2} \frac{1}{T} \int_{-T}^{T} x(t) \cdot x(t-\tau) d t \cdots \ldots \\
& \varphi(\tau)=\frac{1}{T} \int_{-T}^{O} x(t) \cdot x(t-\tau) d t \ldots \ldots \ldots \ldots
\end{aligned}
$$

ここに $\varphi$ は相関関数，ては信号の遅延時間， $T$ は計算 に必要な信号の長さを示す時間, $x(t)$ 注信号である.

ここで $T$ をバブルの振動の周期性を検知するのに必要 な時間に比ベて十分長く，かつバブル発生の間隔に比べ て十分短かく選ぶと (3.4) 式は (3.5) 式の形として表方 すことができる.

$\varphi(\tau, k T)=\frac{1}{T} \int_{k-T}^{k} x(t, k T) \cdot x(t-\tau, k T) d t$

ここに $k$ は $0 ， 1 ， 2 ， 3 \cdots と$ 正の整数值をとる.

また $\varphi(\tau, k T)$ 汇 $\tau=0$ で最大值をとるから (3.6)式 のごとく規格化することができる.

$$
\phi(\tau, k T) \equiv \frac{\varphi(\tau, k T)}{\varphi(0, k T)}
$$

ここで $k T$ を横軸に, “ $\tau ”$ を緹軸にとり, $\phi(\tau, k T)$ を濃淡で表示すると correlategraphが得られる.この解 析例は $T=10 \mathrm{~ms}, \tau=0 \sim 10 \mathrm{~ms}$ まで $」 \tau=100 \mu \mathrm{s}$ の間 隔でとり， $k T$ は 0〜 $2 \mathrm{sec}$ とした. したがつて縦軸の フルスケールが $10 \mathrm{~ms}$ であるから縦軸にあらわれる縞の 数 $\times 100 \mathrm{c} / \mathrm{sec}$ がバブルの基本振動を与えることになる.

sonagram 飞 correlategraph は同じ信号を周波数領 域と時間領域とで解析したもので本質的にはフーリェ変 換によって関係ゔられている.

\section{$3 \cdot 3$ 解析結果}

代表的羽口音の解析例を Photo. 3，4 几示す. (a)は soniagram による解析，(b) は correlategraph 法よる解 析である。

Photo. 3 注正常な羽口の代表例で，Photo. 4 はクラッ 

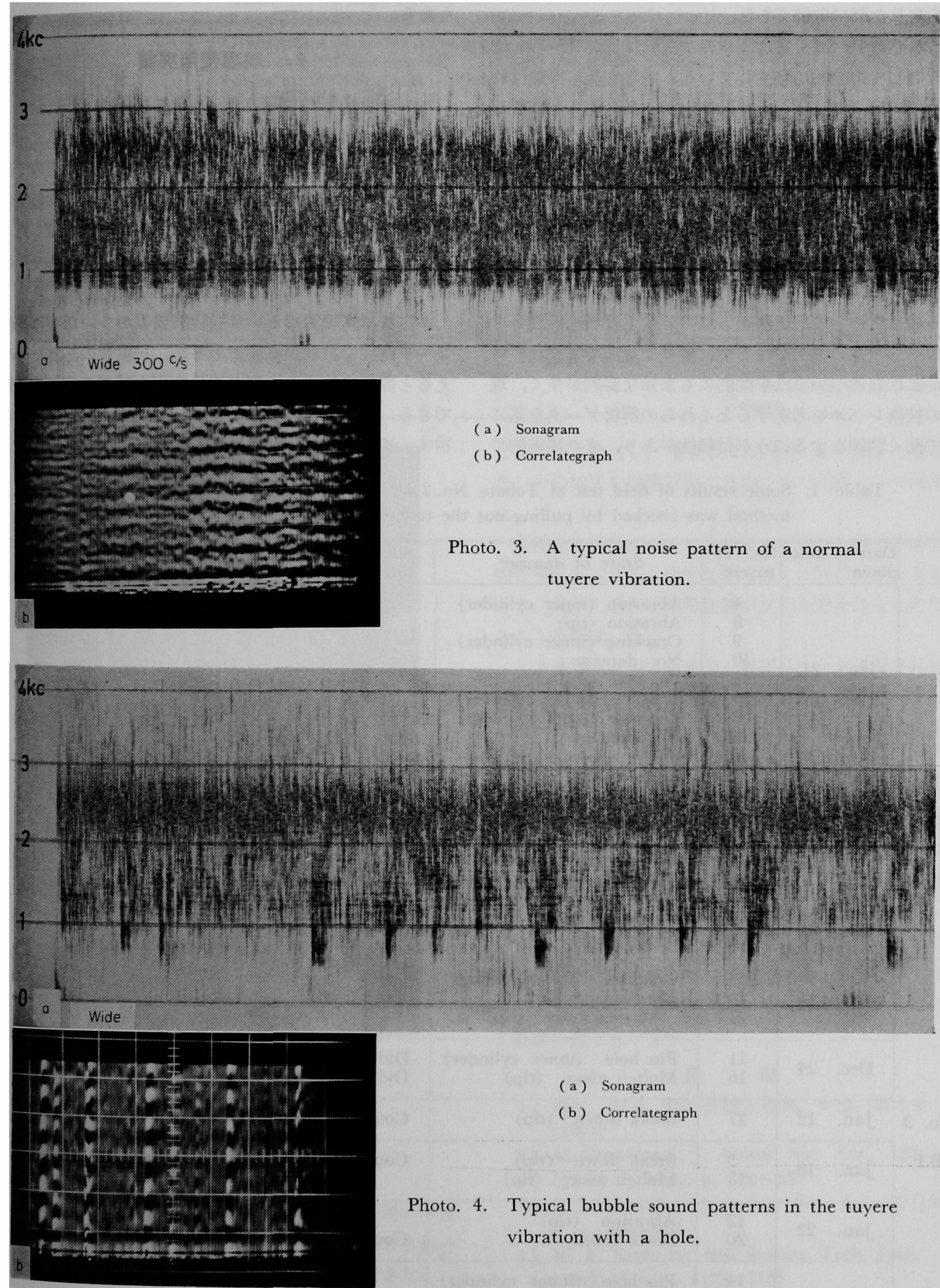

(a) Sonagram

(b) Correlategraph

Photo. 4. Typical bubble sound patterns in the tuyere vibration with a hole. 
クを生じた羽口の例である。

これらによれば正常な羽口では送風雑音が 1〜2 kc 位 に分布して連続的に発生している.中でも基本振動は約 $1 \mathrm{kc}$ 位にあることが correlategraph から明らかに読み とれる.

また破損羽ロでのバブル振動が $1 \mathrm{kc}$ 前後にかたまつ て発生している様子がかかる。雑音は比較的一様なスぺ クトルを持つのに反しバブル音が非常に強い周期性を持 つこと，すなわち固有振動のあることがcorrelategraph からわかる.

一般にこれらの解析法と人間の耳による判別能力とを 比較すると耳の能力が法るかに種々な意味ですぐれてい る.これらについては学問的にも未知な要因が多く, 現 在の技術レベルを考虑するとこれらの解析データを基に 耳で聞く詶練をするほうが信頼性があり，また現実的で

もある。

\section{4. 現場使用実績}

本方法を現場で使用した結果を Table 1 亿示す. （表中×印は破損と判断されたもの，○印正常，一印

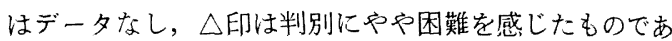
る.)最初の段階では破損頻度が比較的高く，また破損状 況の確認ができる羽口を対象としてデータを集積した。

この結果は本方法採用の初期の頃のデータでありその 後的中卒は $80 \%$ 以上とかなり向上している.

本方法は耳で聞くという経験的要素が多いために最低 $2 \sim 4$ 週間の訓練が必要であるが，一度音の感賞をおぼ えると非常に能率よく羽口や冷却板の破損の有無を検知 できる．この方法の利点を従来法と比較してTable 2 に 示す.また Photo. 5 注実際に使用しているところ学示

Table 1. Some results of field test at Tobata No. 2 and No. 3 B.F. success or failure of this method was checked by pulling out the tuyeres when the furnace was shut down.

\begin{tabular}{|c|c|c|c|c|c|}
\hline & $\begin{array}{l}\text { Date of shut } \\
\text { down }\end{array}$ & $\begin{array}{l}\text { No. of } \\
\text { tuyere }\end{array}$ & State of damage & $\begin{array}{l}\text { Success or failure of } \\
\text { this method }\end{array}$ & Remarks \\
\hline \multirow{5}{*}{$\begin{array}{r}\text { No. } 1 \\
\text { B. F. }\end{array}$} & Jan. 21 & $\begin{array}{r}4 \\
8 \\
9 \\
10 \\
13 \\
15 \\
18 \\
19\end{array}$ & $\begin{array}{l}\text { Abrasion (inner cylinder) } \\
\text { Abrasion (tip) } \\
\text { Cracking (inner cylinder) } \\
\text { No damage } \\
\text { Pin hole (tip) } \\
\text { Cracking (inner cylinder) } \\
\text { Pin hole (inner cylinder) } \\
\text { No damage }\end{array}$ & $\begin{array}{l}s \\
s \\
s \\
s \\
s \\
s \\
f \\
f\end{array}$ & \multirow{3}{*}{$\begin{array}{l}\text { Damages occurred } \\
\text { abruptly }\end{array}$} \\
\hline & Jan. 24 & 7 & Molten away (tip) & Could not be used & \\
\hline & Jan. 31 & 6 & Break down (tip) & Could not be used & \\
\hline & Feb. 15 & $\begin{array}{r}5 \\
20\end{array}$ & $\begin{array}{l}\text { No damage } \\
\text { Pin hole (tip) }\end{array}$ & $f_{s}$ & \\
\hline & Feb. 23 & $\begin{array}{r}2 \\
15\end{array}$ & $\begin{array}{l}\text { Pin hole (tip) } \\
\text { Break down }\end{array}$ & s & \\
\hline \multirow{6}{*}{$\begin{array}{c}\text { No. } 3 \\
\text { B.F. }\end{array}$} & Dec. 21 & $\begin{array}{l}22 \\
24 \\
27\end{array}$ & $\begin{array}{c}\text { Cracking (inner cylinder) } \\
\text { Abrasion (tip) } \\
\text { Molten away (tip) }\end{array}$ & $\begin{array}{l}s \\
s \\
s\end{array}$ & \\
\hline & Dec. 24 & $\begin{array}{l}11 \\
16\end{array}$ & $\begin{array}{l}\text { Pin hole (inner cylinder) } \\
\text { Molten away (tip) }\end{array}$ & $\begin{array}{l}\text { Did not be used } \\
\text { Did not be used }\end{array}$ & \\
\hline & Jan. 12 & 27 & Break down (tip) & Could not be used & \\
\hline & Jan. 16 & $\begin{array}{r}5 \\
18\end{array}$ & $\begin{array}{l}\text { Break down (tip) } \\
\text { Molten away (tip) }\end{array}$ & $\begin{array}{c}\text { Could not be used } \\
s\end{array}$ & $\begin{array}{l}\text { Demages occurred } \\
\text { abruptly }\end{array}$ \\
\hline & Jan. 22 & $\begin{array}{l}12 \\
20\end{array}$ & $\begin{array}{l}\text { Abrasion (tip) } \\
\text { Break down }\end{array}$ & Could not be used & $\begin{array}{l}\text { Damages occurred } \\
\text { abruptly }\end{array}$ \\
\hline & Feb. $\quad 8$ & $\begin{array}{l}14 \\
17 \\
18 \\
21\end{array}$ & $\begin{array}{l}\text { Pin hole (inner cylinder) } \\
\text { Break down } \\
\text { Molten away (tip) } \\
\text { Molten away (tip) }\end{array}$ & $\begin{array}{l}f \\
s \\
s \\
s\end{array}$ & $*$ \\
\hline
\end{tabular}

* abnormal sound was caught once on Jan. 22, but vanished later. 
Table 2. Comparison of the new method with others.

\begin{tabular}{|c|c|c|c|}
\hline & $\begin{array}{l}\text { Observation of water pressure } \\
\text { decrease after shutting off } \\
\text { valves at the inlet and outlet } \\
\text { cooling water pipes }\end{array}$ & $\begin{array}{l}\text { Detection of gas leakage } \\
\text { into the outlet cooling } \\
\text { water pipe }\end{array}$ & This method \\
\hline $\begin{array}{l}\text { Suspension of cooling } \\
\text { water supply }\end{array}$ & Necessary & Not necessary & Not necessary \\
\hline $\begin{array}{l}\text { Additional devices } \\
\text { to cooling water pipes }\end{array}$ & $\begin{array}{l}\text { Bourdon type pressure gage } \\
\left(5 \mathrm{~kg} / \mathrm{cm}^{2}\right) \text { by additional } \\
\text { piping }\end{array}$ & $\begin{array}{l}\text { Gas sampling pipe at } \\
\text { the outlet }\end{array}$ & Not necessary \\
\hline $\begin{array}{l}\text { Time and number of } \\
\text { persons required for } \\
\text { the test }\end{array}$ & $30 \sim 60 \mathrm{~min}$ (four persons) & $10 \sim 20 \min$ (four persons) & $0.5 \sim 2 \mathrm{~min}$ (one penson) \\
\hline Misjudge & Rare & A few & $\left(\begin{array}{l}\text { A few } \\
\text { a normal one is misjudged } \\
\text { to be damaged in a few } \\
\text { cases }\end{array}\right)$ \\
\hline
\end{tabular}

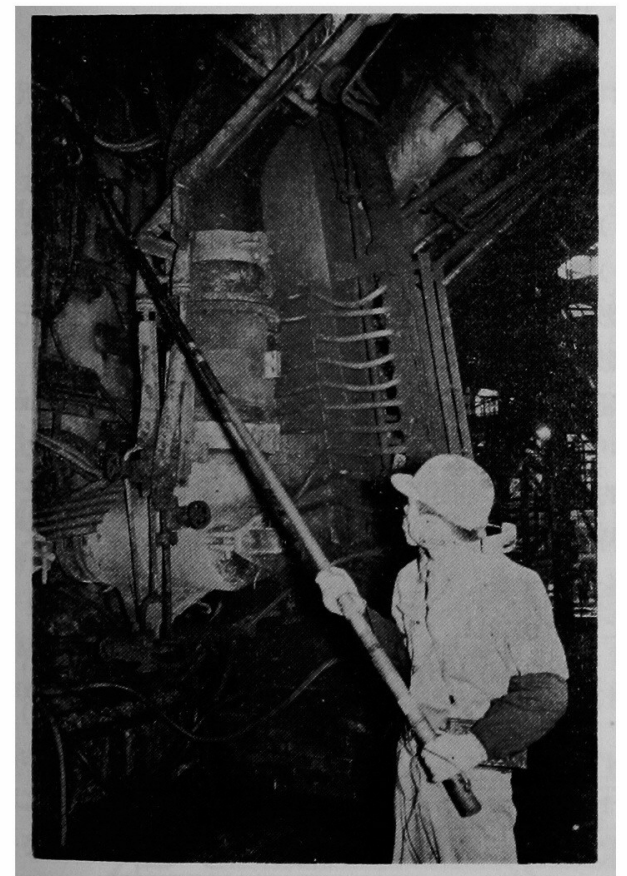

Photo. 5. Under measurement.

す.

\section{5. 結論}

高恼羽口や冷却板の破損検知を音響的手法を用いて検 出する方法について研究し, 㐾来の方法に比較しきわめ て能率よく検知する方法を実用化することができた。

この方法は破損時に生ずるバブルの音を検知する方法 で,バブル音発生のメカニズムやバブル音の特徵を種々
な条件下で検討し，またこれらを数種の方法で解析し た. その結果を現場使用に当たつての指針として活用し た.

最幑に本研究においては雑音として取り扱つた中には 別の角度からみると立派な信号として利用できるものが あり，高炉に関する情報収集の点から興味あるものであ ることを指摘したい.

本方法は日立中央研究所で開発された水道漏水検知器 を基に開発したものであり，終始有益な討議と実験など に多大の協力をいただいた日立中央研究所主管研究員阿 部善右衛門博士, 橋本亨氏に対し厚く御礼申し上げます.

また correlategraph による解析に際し，装置の改造， 借用などを快諾された東大宇宙航空研究所石井泰助教 授, sonagram の解析や医学的立場から種々示唆をいた だいた東京学芸大学教授大和田健次郎医博に対し感謝い たします。

さらに比較的短期間のうちに本研究が完了しえたのは 八幡東研草鹿履一郎理博の適切な指導, 本社鈴木久夫氏 をはじめ多くの方々の援助によるものでありここに改め て感謝の意定表します

\section{文献}

1) 橋本, 阿部，他：計測と制御， 6 巻，第 1 号 (1967)

2 ) M. Strasberg: J. Acoust. Soc. Am., 125 (1953) 3, May, p. 536 537

3 ) S. D. Howkins: J. Acoust. Soc. Am., 37 (1965) 3, p. $504 \sim 508$

4) $W . R$. Bennett: Bell System. Tech. Jour. (1953) Sep. p. 1173 1185

5) 石井“実時間相関計について”学振産業計測, 第36委員会，第 137 回 